\title{
Pulmonary toxicity of components of textile paint linked to the Ardystil syndrome: intratracheal administration in hamsters
}

\author{
F L Clottens, E K Verbeken, M Demedts, B Nemery
}

Laboratory of

Pneumology (Unit of Lung Toxicology), KU

Leuven, Herestraat 49, B-3000 Leuven,

Belgium

F L Clottens

M Demedts

B Nemery

Laboratory of

Histopathology, KU

Leuven,

Minderbroedersstraat

12, B-3000 Leuven,

Belgium

E K Verbeken

Correspondence to:

Dr B Nemery, Laboratory of

Pneumology, KU Leuven,

Herestraat 49, B-3000

Leuven, Belgium.

Accepted 18 December 1996

\begin{abstract}
Objectives-It was hypothesised from an epidemiological investigation that a formula change from Acramin FWR (a polyurea) to Acramin FWN (a polyamideamine) had led to severe pulmonary disease in textile printing sprayers in Spain and Algeria. To verify this, the pulmonary toxicity of the components of the paint systems involved was assessed in experimental animals.
\end{abstract}

Methods-Individual components and relevant mixtures, diluted in phosphate buffered saline, were given by intratracheal instillation of $2 \mathrm{ml} / \mathrm{kg}$ to hamsters. Pulmonary toxicity was assessed on days $3,7,14,28$, and 92 after a single intratracheal instillation, by histology and by measuring wet and dry lung weight, protein concentration, the activities of lactate dehydrogenase, alkaline phosphatase, $\beta$-N-acetyl-glucosaminidase, and $\gamma$-glutamyltransferase, inflammatory cell number and distribution in bronchoalveolar lavage fluid (BALF), and hydroxyproline content in dried lung tissue.

Results-Based on the doses that killed $50 \%$ of the animals $\left(L D_{50} s\right)$, the various components were found to be 10 to 1250 times more toxic when given intratracheally than when given orally (according to reported oral $\mathrm{LD}_{50} \mathrm{~s}$ in rats). Acramin FWN, Acramin FWR, Acrafix FHN, or their mixtures caused lung damage. Protein concentration, enzyme activities, total cell number, and percentage of polymorphonuclear neutrophils were increased in BALF during the first week after intratracheal instillation. Lung weights remained high for at least a month. Histology showed inflammatory cell infiltration and subsequent fibrosis with collagen deposition. This finding was confirmed by an increased hydroxyproline content in dried lung tissue. Acramoll W did not show toxic effects.

Conclusions-The study suggests that there is no major difference, in hamsters, between the acute intratracheal toxicity of Acramin FWR and that of Acramin FWN. Consequently, there is no simple toxicological explanation for the epidemiological hypothesis. However, the pulmonary toxicity of these non-irritant polymeric compounds is surprisingly high. The Ardystil disaster and these results should serve as a strong warning that conventional toxicity testing of chemicals does not necessarily protect workers against respiratory toxicity.

\section{(Occup Environ Med 1997;54:376-387)}

Keywords: Ardystil; pulmonary toxicity; Acramin paint system; organising pneumonia

Early in 1992, an outbreak of severe respiratory disease occurred in the Community of Valencia, Spain. An epidemiological study, ${ }^{1}$ conducted among 257 workers from eight textile printing factories in the area, identified 22 cases with radiological or histological evidence of interstitial lung disease, described as organising pneumonia. Most cases had worked in a factory, called "Ardystil", where textiles were air sprayed with dyes using the Acramin F paint system. The disease proved fatal over the course of a few months in six of these subjects, five young women and one 52 year old man. Later, a similar outbreak took place in Tlemcen, Algeria, where one young women died and at least two others were affected by severe interstitial lung disease after having worked in a small textile factory which used similar products and techniques as the Ardystil plant. ${ }^{2}$

So far, the exact causal agent for this dramatic outbreak of occupational pulmonary disease is not known. To our knowledge and that of the experts who carried out the investigations, no outbreak of respiratory disease of the kind found in these textile sprayers has been described previously. The Acramin F paint system, made by Bayer, has been in use since the early 1950 s for dying textiles and it has not been reported to lead to adverse respiratory effects. Admittedly, this paint system was intended to be applied as a paste for screen printing, and not as an aerosol by air brushing. Moreover, hygiene conditions in the factories involved seem to have been very poor, with the workers being exposed to very high concentrations (up to $10 \mathrm{mg} / \mathrm{m}^{3}$ ) of aerosolised paint. ${ }^{1}$ Nevertheless, the subacute time course, the unusual presentation, and the extreme severity of the disease are puzzling, particularly because 
Acramin FWR

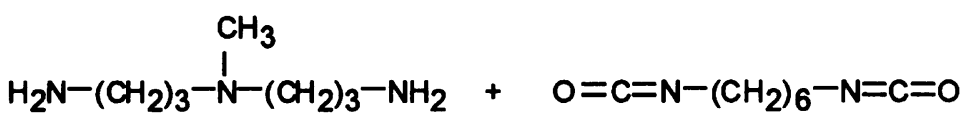

Bis-(3-aminopropy)methylamine Hexamethylenedisocyanate<smiles>CN(CCN)CCNC(=O)NCCNC(=O)NCCN(C)CCN</smiles>

\section{Acramin FWN}<smiles>NCCN(CCN)CCN</smiles>

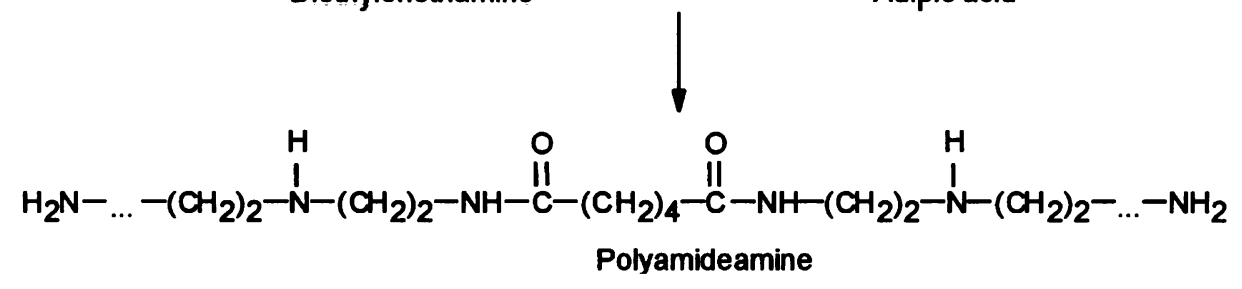

Acrafix FHN

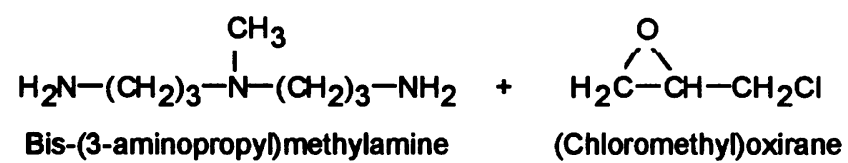

Acramoll W

$$
\begin{aligned}
& \stackrel{\mathrm{O}}{\mathrm{H}} \underset{3}{\mathrm{C}}-\left(\mathrm{CH}_{2}\right)_{3}-\mathrm{O}-\mathrm{C}-\mathrm{CH}=\mathrm{CH}_{2}+\stackrel{\mathrm{Cl}-\mathrm{C}-\mathrm{Cl}}{\stackrel{\mathrm{CH}}{1}} \\
& \text { Butyl acrylate }
\end{aligned}
$$

Figure 1 Structural formulas of the components of the Acramin F paint system or their precursors (Acramin FWR, Acramin FWN, Acrafix FHN, and Acramoll W).

these polymers (see fig 1 for their structural formulas) would not be expected, from a toxicological viewpoint, to cause such spectacular pulmonary damage, even when inhaled as aerosols. According to the manufacturer's material safety data sheets, the paint components of the Acramin F system were considered, on the basis of standard toxicity testing procedures, to be non-irritant to the skin or eyes. Hence, if the aerosolised paint, or one of its components, really caused the serious pulmonary disease found in these workers, it is of great importance, both in theory and in practice, to understand the mechanisms for this respiratory toxicity.

Reasonable epidemiological evidence indicates that the outbreak was associated, both temporally and geographically, with a formula change from Acramin FWR (a polyurea) to Acramin FWN (a polyamide-amine) in the paint system used, with both agents having been applied in aerosol form. ${ }^{1}$ Therefore, the main purpose of the present study was to verify whether there was a substantial difference between the acute pulmonary toxicity of these two components, either when administered alone or in combination with the other ingredients of the paint. Also, two other components present in the Acramin F paint system (Acrafix FHN and Acramoll W), were tested to assess their possible contribution to the toxicities of the paint mixtures. The intratracheal route was chosen because of its simplicity and in the full knowledge of its limitations.

\section{Materials and methods}

ANIMALS

Male and female Syrian golden hamsters were bred in the animal unit of the KU Leuven. Animals were six to 15 weeks old and weighed 80 to $120 \mathrm{~g}$. (Younger animals were chosen to study the long term effects and older animals for the short term effects; within each experiment the mean ages were similar across the different treatment groups.) The animals were housed as experimental groups in a conventional animal house, with a $12 / 12 \mathrm{~h}$ light/dark 
cycle, in standard polyethylene cages covered with a stainless steel lid. They received unlimited water and pelleted food and were not starved before dosing. Experiments were conducted in accordance with national legislation guidelines, which comply with the guiding principles in the use of animals in toxicology.

INTRATRACHEAL INSTILLATION

On day 0 the hamsters $(n=5$ per experimental group) received a single intratracheal instillation of the relevant component or mixture. The animals were anaesthetised with $40 \mathrm{mg} / \mathrm{kg}$ intraperitoneal pentobarbitone (Nembutal, Sanofi, Aalst, Belgium), and a 22 gauge, $25 \mathrm{~mm}$ long Insyte-W catheter (Becton Dickinson, Sandy UT, USA) was inserted through the mouth into the trachea. The correct location of the catheter was verified by the observation of exhaled water vapour on a chilled metal blade with each breath of the animal. The volume instilled was always $2 \mathrm{ml} / \mathrm{kg}$ body weight and the instillation was followed by the insufflation of an air bolus through the catheter to achieve dispersion of the instillate. This procedure has been in use for many years in our laboratory and it is generally well tolerated by the hamsters. Some animals needed to be resuscitated by gentle massage of the thorax after the instillation. This was often the case after instillation of Acramin FWR or mixture 1. Only rarely $(<5 \%)$ did an animal not recover from the anaesthesia. Animals that died prematurely were replaced to obtain $n=5$ whenever possible.

\section{CHEMICAIS}

Acramin FWN (lot No T-56232), Acramin FWR (lot No K-0529), Acrafix FHN (lot No T-59903), and Acramoll W (lot No A-43-) were provided by Bayer AG (Leverkusen, Germany). All these products are liquids, except Acramin FWR, which is a powder. As the molecular weights of these polymers were not known, the doses could not be expressed as moles of product. They are given here as $\mathrm{mg} / \mathrm{kg}$ body weight, taking into account the densities given by the supplier $(1.1 \mathrm{~g} / \mathrm{ml}$ for all four chemicals). The doses to be given were determined from the proportions of each ingredient reportedly used in the relevant paint formulations (table 1). Mixture 1 corresponded to the formulation, containing Acramin FWR, used in the Ardystil plant before the formula change, whereas mixture 3 corresponded to the formulation, containing Acramin FWN, used after the formula change. Mixture 2 was similar to mixture 3, except that white spirit and acetic acid were omitted. The white spirit (Stoddard solution) used was purchased from a local store. All dilutions were made with phosphate buffered saline (PBS=137 mM NaCl, $27 \mathrm{mM} \mathrm{KCl,} 15 \mathrm{mM}$ $\left.\mathrm{KH}_{2} \mathrm{PO}_{4}, 10.6 \mathrm{mM} \mathrm{Na} \mathrm{HPO}_{4}, \mathrm{pH} 7.4\right)$. An Acramin FWR stock solution (0.5 g Acramin FWR powder; $3.5 \mathrm{ml}$ distilled water; $1.0 \mathrm{ml}$ $30 \%$ acetic acid) was prepared in advance according to the manufacturer's notes. The
Table 1 Concentrations of individual components in the Acramin F paint systems and intratracheal doses in hamsters

\begin{tabular}{lll}
\hline & $\begin{array}{l}\text { Concentration } \\
\text { in paint mixture } \\
(\%)\end{array}$ & $\begin{array}{l}\text { Dose } \\
(\mathrm{mg} / \mathrm{kg})\end{array}$ \\
Compounds & & 33.0 \\
Acramoll W & & 6.6 \\
Acrafix FHN & & 2.0 \\
Acramin FWR & & 16.5 \\
Acramin FWN & 10 & 22.0 \\
Mixture 1: & 2 & 4.4 \\
Acramoll W & 1 & 2.0 \\
Acrafix FHN & & \\
Acramin FWR & 15 & 33.0 \\
Mixture 2: & 3 & 6.6 \\
Acramoll W & 7.5 & 16.5 \\
Acrafix FHN & & \\
Acramin FWN & 15 & 33.0 \\
Mixture 3: & 3 & 6.6 \\
Acramoll W & 7.5 & 16.5 \\
Acrafix FHN & 13 & 20.3 \\
Acramin FWN & 2 & 2.5 \\
White spirit & & \\
Acetic acid (60\%) & & \\
\hline
\end{tabular}

The volume instilled was always $2 \mathrm{ml} / \mathrm{kg}$ body weight. The doses given correspond to a $1: 10$ dilution in phosphate buffered saline of the final concentration in the paint. The concentrations of the mixtures are based on a report by Riveira Rico et al.

other mixtures and dilutions were prepared a few hours before administration.

DETERMINATION OF LETHALITY

In a preliminary study, intratracheal lethal doses that killed $50 \%$ of the animals $\left(\mathrm{LD}_{50} \mathrm{~s}\right)$ were found for Acrafix FHN (top dose 66 $\mathrm{mg} / \mathrm{kg}$ ), Acramin FWR (top dose $20 \mathrm{mg} / \mathrm{kg}$ ), Acramin FWN (top dose $165 \mathrm{mg} / \mathrm{kg}$ ), and Acramoll W (top dose $1320 \mathrm{mg} / \mathrm{kg}$ ). Animals were monitored for seven days for body weight and mortality. Survivors were necropsied after seven days and their lungs examined histologically.

The $\mathrm{LD}_{\overline{1}, 1} \mathrm{~s}$ were assessed with the smallest possible numbers of animals to obtain meaningful results. We used the tables of Weil, which allow the use of as few as two animals per dose level, with four logarithmically spaced dose levels (doses were decreased by a factor of five in the case of Acramin FWN, Acramin FWR, and Acrafix FHN and by a factor of two in the case of Acramoll W). Due to the low numbers of animals per dose level, it was not possible to obtain meaningful estimates of confidence intervals.

\section{EXPERIMENTAL PROTOCOL AND END POINTS} MEASURED

All animals were observed and weighed daily during the first week after dosing, and then once a week. On days $3,7,14,28$, or 92 days after the intratracheal instillation, animals were anaesthetised with an intraperitoneal overdose of Nembutal $(120 \mathrm{mg} / \mathrm{kg})$. The abdomen was opened and the abdominal aorta was cut to exsanguinate the animal. After opening the thorax, the left bronchus and pulmonary vessels were clamped and the left lung was removed, weighed (wet lung weight), and placed in an oven at $60^{\circ} \mathrm{C}$ for 48 hours. Dry lung weight was obtained after the tissue had equilibrated to room temperature. Wet and dry lung weights are expressed relative to body 
weight at the time of death, with a correction factor being applied for the sex of the animal, as female hamsters have a $14 \%$ higher relative lung weight than males (unpublished observation).

The right lung was lavaged in situ four times with $1 \mathrm{ml} 0.9 \% \mathrm{NaCl}$ at room temperature through a 14 gauge Insyte-W catheter inserted into the trachea through a cut in the cricoid membrane. After its recovery, the pooled bronchoalveolar lavage fluid (BALF) was kept on ice until centrifugation at $250 \mathrm{~g}$ for 10 minutes at $4^{\circ} \mathrm{C}$. The supernatant was assayed for total protein concentration, activities of lactate dehydrogenase $(\mathrm{LDH})$, alkaline phosphatase (ALP), $\beta$-N-acetyl-glucosaminidase (NAG), and $\gamma$-glutamyltransferase $(\gamma-G T)$. The pellet was resuspended in $200 \mu \mathrm{PBS}^{+}$(PBS containing $1 \%$ bovine serum albumin (BSA) and $0.1 \%$ $\mathrm{NaN}_{3}$ ) and used for total and differential cell counts.

Finally, the right lung was instilled, with a syringe with $10 \%$ formaldehyde until full expansion of the different lobes for light microscopy histological studies, or in some animals, with $6.5 \%$ glutaraldehyde (in PBS) for possible electron microscopy studies.

TOTAL AND DIFFERENTIAL CELL COUNTS

A $40 \mu \mathrm{l}$ aliquot of the cell suspension was diluted in $20 \mathrm{ml}$ Isoton II fluid (Coulter Electronics, Luton, UK) and the total cell number was counted in a DN Coulter counter, after lysis of the red blood cells with Zap-Oglobin (Coulter). The total cell numbers reported in this study are the numbers of cells recovered from the BALF of the right lung. An aliquot of the BALF cell suspension, containing about 20000 cells, was diluted in $0.5 \mathrm{ml} \mathrm{PBS}^{+}$and placed in a sample chamber of a Cytospin-3 cell centrifuge (Shandon Scientific, Cheshire, UK) as indicated in the manufacturer's recommendations. Slides were stained with the Dade Diff-Quik staining set for cell typing (Baxter Diagnostics AG, Düdingen, Switzerland). The distribution of inflammatory cells (excluding erythrocytes and epithelial cells) was determined by counting $3 \times 100$ cells at a magnification of $100 \times$ under oil immersion.

BIOCHEMICAL VARIABLES

Total protein concentration was measured by the method of Bradford, ${ }^{6}$ with the Bio-Rad microassay procedure (Bio-Rad Laboratories NV, Nazareth, Belgium). Activity of LDH was measured by the method, described by Vassault. $^{7}$ Activities of ALP and $\gamma$-GT were measured with Sigma kits (respectively, No 104-LL and No 419-10, Sigma Germany, through Filter Service, Eupen, Belgium) as indicated in the manufacturer's protocol. Activity of NAG was measured by the method of Horak et al. ${ }^{8}$ The hydroxyproline content in dried lung tissue was measured by the method of Woessner. ${ }^{9}$

HISTOLOGY

Transverse sections of the middle, basal, and accessory lobes of the right lung were embed-
Table 2 Intratracheal $L D_{s_{0}}$ of the individual components of the Acramin F paint system

\begin{tabular}{lll}
\hline Component & $\begin{array}{l}\text { Doses } \\
(\mathrm{mg} / \mathrm{kg} \text { body weight })\end{array}$ & $\begin{array}{l}\text { Intratracheal } L D_{\mathrm{so}} \\
(\mathrm{mg} / \mathrm{kg} \text { body weight })\end{array}$ \\
\hline $\begin{array}{l}\text { Acramoll W } \\
\text { Acramin }\end{array}$ & $1320-660-330^{\star}-165$ & 467 \\
$\begin{array}{l}\text { FWN } \\
\text { Acrafix FHN }\end{array}$ & $165^{\star}-33-6.6-1.3$ & 43 \\
$\begin{array}{l}\text { Acramin } \\
\text { FWR }\end{array}$ & $20^{\star}-4-0.8-0.13 .6-0.5$ & 30 \\
\hline
\end{tabular}

* Correspond to the final concentration in the paint. The paint concentrations are based on a report by Riveira Rico et al $; \mathrm{n}=$ 3 per dose for Acramin FWN, $n=2$ per dose for all other components. The volume instilled was always $2 \mathrm{ml} / \mathrm{kg}$ body weight.

ded in paraffin and $4 \mu \mathrm{m}$ sections were stained with haematoxylin and eosin and with Masson's trichrome stain for collagen. The histological sections of one animal per group (every third animal) were evaluated by a person (EKV) blinded to the origin of the specimen.

STATISTICAL ANALYSIS

Results were compared with a one way analysis of variance applied to ranks (Kruskal-Wallis), followed by Dunnett's multiple comparisons test (treated versus control) or Bonferroni's multiple comparisons test (PC program: SAS, version 6.04).

\section{Results}

$\mathrm{LD}_{50}$ OF THE INDIVIDUAL COMPONENTS

All animals given doses corresponding to the pure paint concentrations of the components died during the first hours after instillation, except in the case of Acramoll W. No animal died after the administration of doses corresponding to $1 / 25$ th of the paint concentration, or less. At doses corresponding to $1 / 5$ th of the paint concentration, Acramin FWN (33 mg/ $\mathrm{kg}$ ), Acramin FWR (4 mg/kg) and Acrafix FHN $(13.2 \mathrm{mg} / \mathrm{kg}$ ) caused respiratory distress and mortality within 48 hours after instillation. Table 2 summarises the intratracheal $\mathrm{LD}_{50}$ figures in hamsters. For comparison: the values for oral $\mathrm{LD}_{50}$ in rats, as indicated in the material safety data sheets provided by the manufacturer, are $>5000 \mathrm{mg} / \mathrm{kg}$ for Acramoll W, Acramin FWR, and Acrafix FHN; and $>2000$ $\mathrm{mg} / \mathrm{kg}$ for Acramin FWN. The intratracheal $\mathrm{LD}_{50}$ s obtained are, therefore, 10 to 1250 times lower than the reported oral $\mathrm{LD}_{50}$ in rats, indicating that these compounds are 10 to 1250 times more toxic when given intratracheally than when given orally. Body weight decreased until three days after the intratracheal instillation when doses corresponding to up to $1 / 25$ th of the relative paint concentration were applied (Acramoll W $13 \mathrm{mg} / \mathrm{kg}$; Acramin FWN 6.6 $\mathrm{mg} / \mathrm{kg}$; Acrafix FHN $2.6 \mathrm{mg} / \mathrm{kg}$; Acramin FWR $0.8 \mathrm{mg} / \mathrm{kg}$ ). Thereafter, the body weight increased again (data not shown). In the subsequent experiments, doses corresponding to $1 / 10$ th of the relative paint concentration were applied. These doses were chosen to cause toxicity but little or no lethality.

TOXICITY OF THE INDIVIDUAL COMPONENTS Figure 2 shows the results from Acramin FWN and Acramin FWR, which were the agents of 


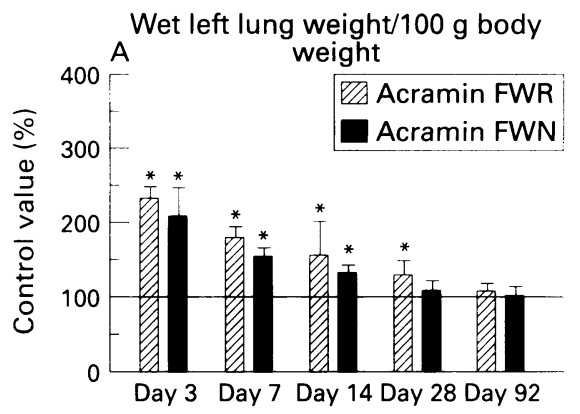

Time after intratracheal instillation

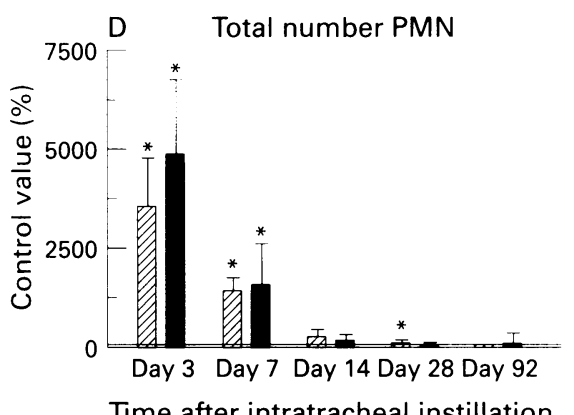

Time after intratracheal instillation

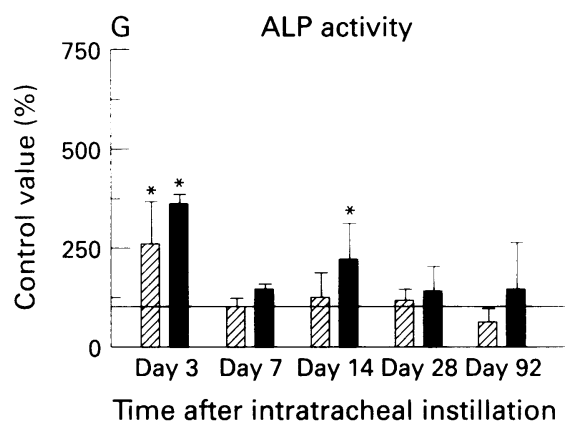

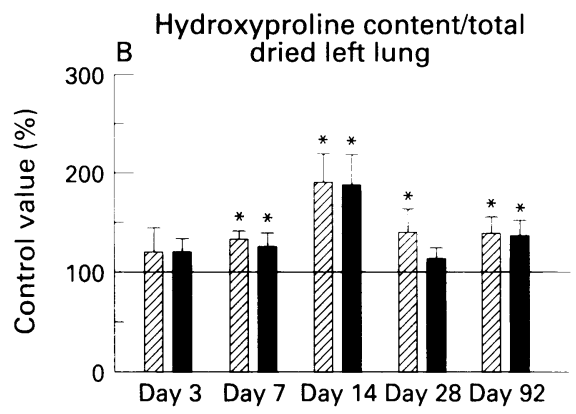

Time after intratracheal instillation
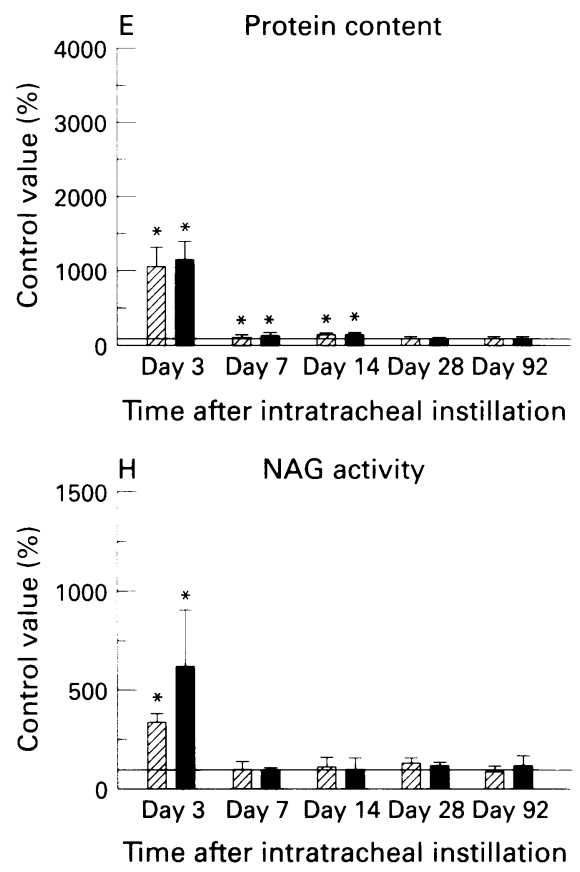

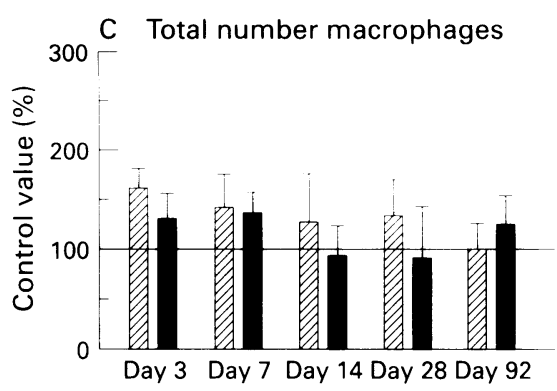

Time after intratracheal instillation
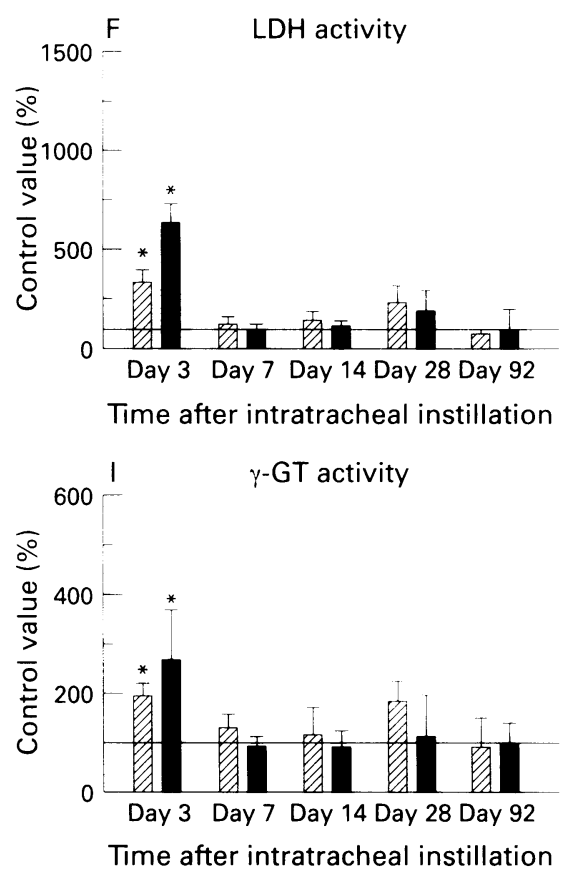

Figure 2 Lung weight, hydroxyproline content, cell count, and indices in BALF after a single intratracheal instillation of 2.0 mg/kg Acramin FWR or $16.5 \mathrm{mg} / \mathrm{kg}$ Acramin FWN in hamsters. All results are expressed as percentages of control values (SD). The statistical indications ( $\left.{ }^{\star} P<0.05\right)$ on the graphs (Dunnett's multiple comparisons test after one way analysis of variance (ANOVA) applied to ranks) were derived from the analysis made on the absolute values (appendix). No significant differences were found between Acramin FWR and Acramin FWN for any of the variables assessed (Bonferroni's multiple comparisons test).

the greatest interest. Tables with complete results are given as appendixes $1-3$.

The data from control animals were stable and conform to expectations and our findings in previous studies. After two weeks in the conventional animal house there was an increase in polymorphonuclear neutrophils in the BALF, but this was not associated with any biochemical sign of pulmonary damage.

Acramin FWR and Acramin FWN led to clear signs of acute lung toxicity with a twofold increase in wet lung weight on day 3 . The ratio of wet:dry lung weight was not altered or only slightly increased. The number of cells in the BALF was greatly increased and this was mainly due to an influx of polymorphonuclear neutrophils. There were no significant changes in lymphocytes and eosinophils. Body weight was decreased by up to $8 \%$ on day 3 , after which it started increasing again. After day 14, body weight followed the growth curve of control animals (data not shown). Biochemically, the toxicity was characterised by large increases in protein content and LDH, ALP, NAG, and $\gamma$-GT activities in BALF. Most of these indices had returned to normal values by seven days after the instillation, except for protein which remained marginally but significantly increased until day 14 after dosing. Lung weight also tended to return towards normal values, but wet lung weight was still significantly increased on day 14 (Acramin FWN) and day 28 (Acramin FWR). Hydroxyproline content was the only variable which was not altered on day 3, but was significantly higher for both Acramin FWR and Acramin FWN from day 7 onwards and remained so until day 92 . Although BALF enzyme activities tended to be increased more after Acramin FWN, the difference from Acramin FWR was at no point significant.

Acrafix FHN also resulted in acute pulmonary toxicity, with transient and less pronounced increases in lung weight, polymorphonuclear neutrophil influx, and protein leakage. Initial decrease of body weight on day 3 was also less pronounced. There were little or no changes in BALF enzymes, and no increase in hydroxyproline.

At the dose given, Acramoll $\mathrm{W}$ proved to be devoid of any toxicity, except for an increased number of polymorphonuclear neutrophils in BALF on days 3 and 7 after instillation. 


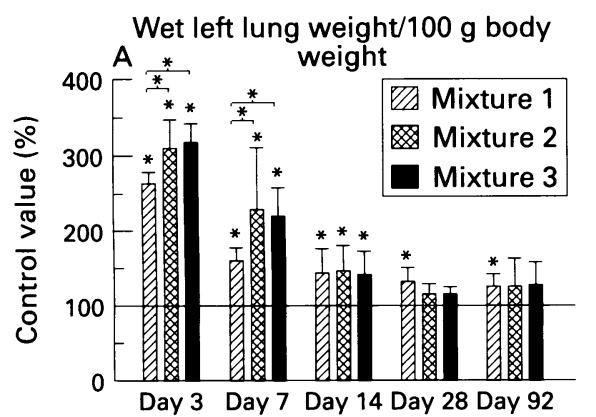

Time after intratracheal instillation
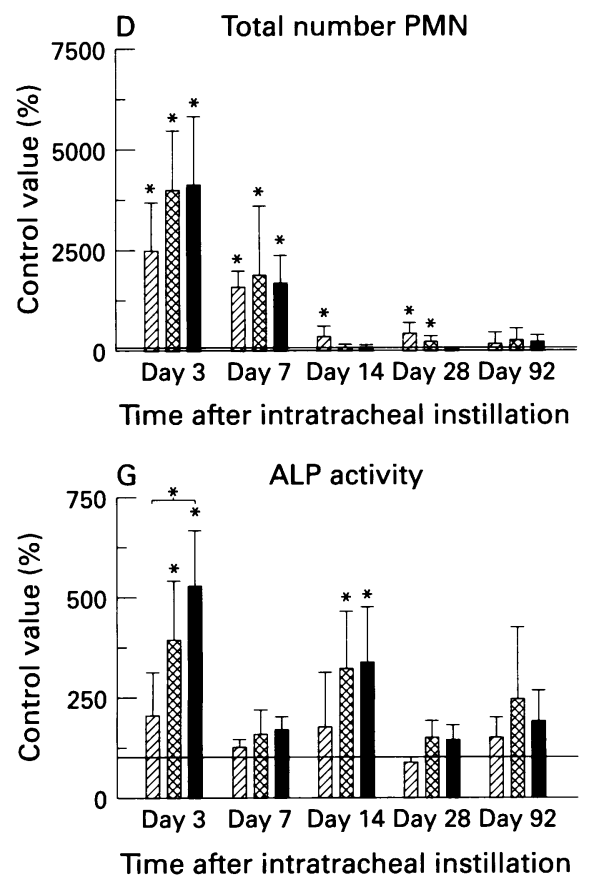

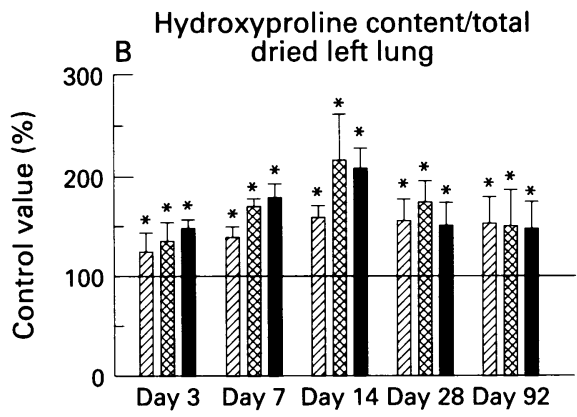

Time after intratracheal instillation
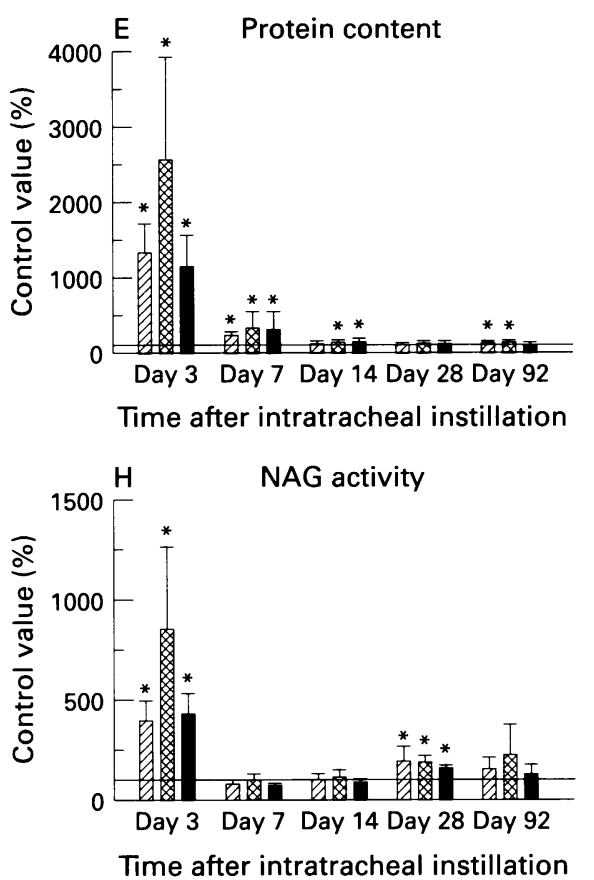

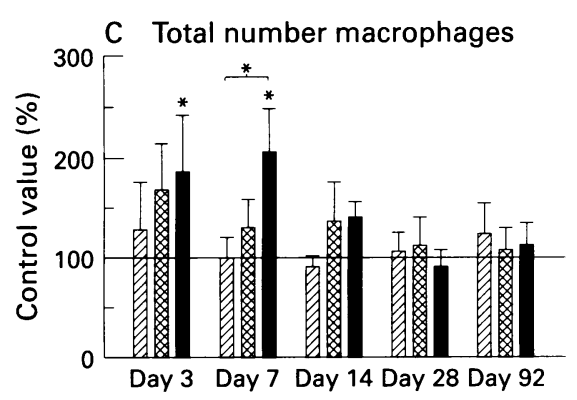

Time after intratracheal instillation

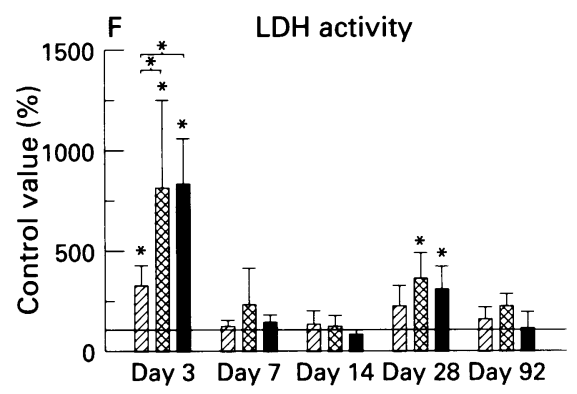

Time after intratracheal instillation

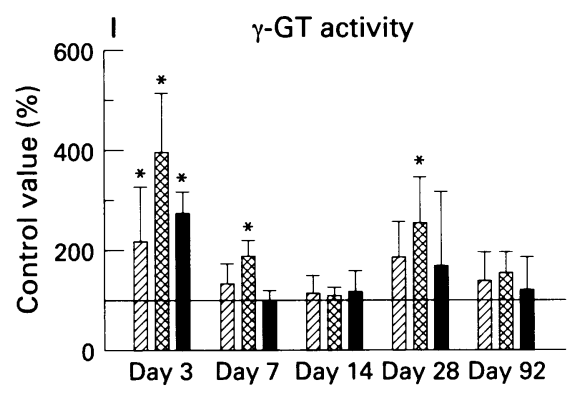

Time after intratracheal instillation

Figure 3 Lung weight, hydroxyproline content, cell count, and indices in BALF after a single intratracheal instillation in hamsters of three mixtures: mixture 1 containing Acramin FWR and mixtures 2, and 3 containing Acramin FWN (see table 1). All results are expressed as percentages of control values (SD). The statistical indications ${ }^{\star} P<0.05$ ) on the graphs (Dunnett's multiple comparisons test after one way ANOVA applied to ranks) are derived from the analysis made on the absolute values (appendixes 1-3). Statistical differences between the mixtures (Bonferroni's multiple comparisons test) are indicated $(* P<0.05)$.

TOXICITY OF THE MIXTURES

Figure 3 summarises these results and complete results are given as an appendix.

In general, the mixtures led to qualitatively similar but quantitatively more pronounced effects than when Acramin FWR or Acramin FWN had been given separately. Twenty per cent of all the animals given mixture 2 or 3 died between 24 to 72 hours after instillation. Body weight was decreased by $10 \%$ to $12 \%$ of initial body weight on day 3 , after which it increased again.

Wet lung weight was increased 2.5-fold to threefold on day 3 and ratios of wet to dry weight were slightly increased. There was again evidence of a massive influx by polymorphonuclear neutrophils. Biochemical indices in BALF again showed early increases in protein content and in enzyme activities. Some of these variables were still significantly different from those of controls at later times, but these alterations were not systematic. Total lung hydroxyproline was consistently increased throughout the observation period.
There were no differences between the effects of mixture 2 and those of mixture 3 (containing a mixture of aliphatic solvents). When compared with mixture 1 , mixtures 2 or 3 led to a significantly higher wet lung weight and absolute number of macrophages (day 3 and 7), and to significantly higher values of $\mathrm{LDH}$ and ALP activities (day 3).

MACROSCOPIC FINDINGS AND LUNG HISTOLOGY At necropsy, no apparent lesions were found in control animals or animals treated with Acramoll W. No gross abnormalities were noticed in major abdominal organs in any of the animals examined. After instillation of Acramin FWN, Acramin FWR, Acrafix FHN, or mixtures containing these components, focally distributed haemorrhagic areas were found on the lungs. Occasionally, entire lung lobes had become consolidated. No specific component or mixture could be singled out as causing more pronounced macroscopic lung damage.

The histopathology of lung tissues after intratracheal instillations of Acramin FWR, 
Acramin FWN, Acrafix FHN, or different mixtures containing these components, showed a fulminant inflammation of the parenchyma surrounding the distal bronchioles (fig 4). In the epithelial lining of the airways, Clara cells were lacking during the acute response on day 3 and epithelial cells appeared stressed. Neutrophil and mononuclear inflammatory cell infiltration occurred and there was hyperplasia of alveolar type II cells. The alveoli contained infiltrations of red blood cells. A loosely knit early fibrosis was noticed. In all specimens except those from control animals, granules were found in the cytoplasm of the alveolar macrophages, thus indicating penetration of material into the lung parenchyma. When hamsters had been instilled with Acramoll W, no pulmonary lesions were found, except for the granules in the macrophages and some inflammatory cell infiltration.

On day 7, less inflammatory cell infiltration was found and the histopathology was changed towards that of interstitial fibrosis with the start of collagen deposition. The epithelial lining looked normal, but there was still hyperplasia of type II cells. On days 14,28 , and 92 inflammatory cell infiltration was almost absent. In affected focal areas, the alveolar walls were enlarged, with signs of interstitial collagen deposition, indicating fibrosis. All chemicals, with the exception of Acramoll W, resulted in a similar histopathology.

\section{Discussion}

Except after acute inhalation accidents, occupational respiratory disease that is fatal over a few months of exposure is a rare occurrence by any standards. When a rare interstitial lung disease, such as cryptogenic organising pneumonia (also referred to as bronchiolitis obliterans with organising pneumonia) suddenly occurs in almost epidemic proportions, as was the case in textile workers from Spain ${ }^{1}$ and Algeria, ${ }^{2}$ serious efforts should be made to discover the exact origin and the mechanisms for this unexpected occurrence to prevent similar cases in the future. It could be argued that the paints used by these workers were not meant to be applied by air brushing and that hygiene conditions in these workshops were appalling, but this is not sufficient to explain the spectacular course of the disease in a few plants only, because the air spraying of textiles seems to have been practised, without apparent problems, for some time before the outbreak and in other similar workshops where no major lung diseases were reported. It is, therefore, reasonable to hypothesise that something peculiar caused the Ardystil syndrome.

On the basis of an epidemiological study conducted in Spain months after the outbreak, the hypothesis was put forward that the lung disease which had developed in these workers, resulted from the replacement in the paint system of one component, Acramin FWR, by another, Acramin FWN. ${ }^{1}$ Although the arguments put forward in support of this hypothesis were sound, the evidence was only based on a temporal and geographical association and it is difficult to understand from a toxicological viewpoint why and how the newly introduced substance should have been so much more toxic than the old one. Both compounds are polymers, one a polyurea and the other a polyamide-amine, with no particular structural alerts (see fig 1) and they had been found to be non-irritating on the basis of conventional tests of irritancy for the skin and eyes.

The principal objective of our study was to verify if there was any major difference in the pulmonary toxicities of Acramin FWN and Acramin FWR, whether given alone or in combination with the other ingredients of the incriminated paints. In other words, our aim was not to discover possible subtle differences between two chemical agents, but to find out whether their direct pulmonary effects differed substantially. Until now, not even the most elementary information was publicly available on the acute pulmonary toxicity of these compounds and yet one of them had allegedly caused death in several human subjects. Thus, it was not inconceivable that the acute lung toxicities of the two agents might have differed by orders of magnitude.

For the toxicity evaluation of the different chemicals the intratracheal instillation route was chosen. We are fully aware of the limitations of this route of administration when compared with the more physiologically relevant inhalation technique. These limitations apply mainly to the rate of delivery of the toxic agent (a bolus instillation may suddenly overwhelm the pulmonary defence systems, as opposed to a continuous low dose rate of an inhaled agent) and to the distribution pattern of the material (more uneven and more proximal deposition after instillation, than after inhalation). ${ }^{10}$ However, the simple and inexpensive technique of intratracheal instillation was the only method which was readily available to us. It was also the only realistic option if we wanted to test, within a reasonable time and cost, not only the two components themselves, but also their relevant combinations with other ingredients of the paints. Moreover, despite the known drawbacks of the intratracheal route, several excellent mechanistic studies of pulmonary toxicity have been conducted with intratracheal instillations in rats $^{11}$ or hamsters. ${ }^{12}$ Hamsters were chosen because they were readily available to us but also because they tolerate intratracheal instillations well and they are well suited for studies of pulmonary fibrosis. ${ }^{13}$ The doses given $(10 \%$ of the concentration of the different components in their respective paint mixture) were based on the results of a preliminary study, in which the approximate intratracheal $\mathrm{LD}_{50}$ was assessed, and they were expected to cause toxicity, but little or no lethality.

One of our initial concerns was that the airways of the animals might simply become clogged by a liquid, thereby causing hyperacute deaths by asphyxia. However, with the volumes given (about $200 \mu \mathrm{l}$ per hamster), this did not happen, except, to some extent, in the case of Acramin FWR and mixture 1. Dosing with 

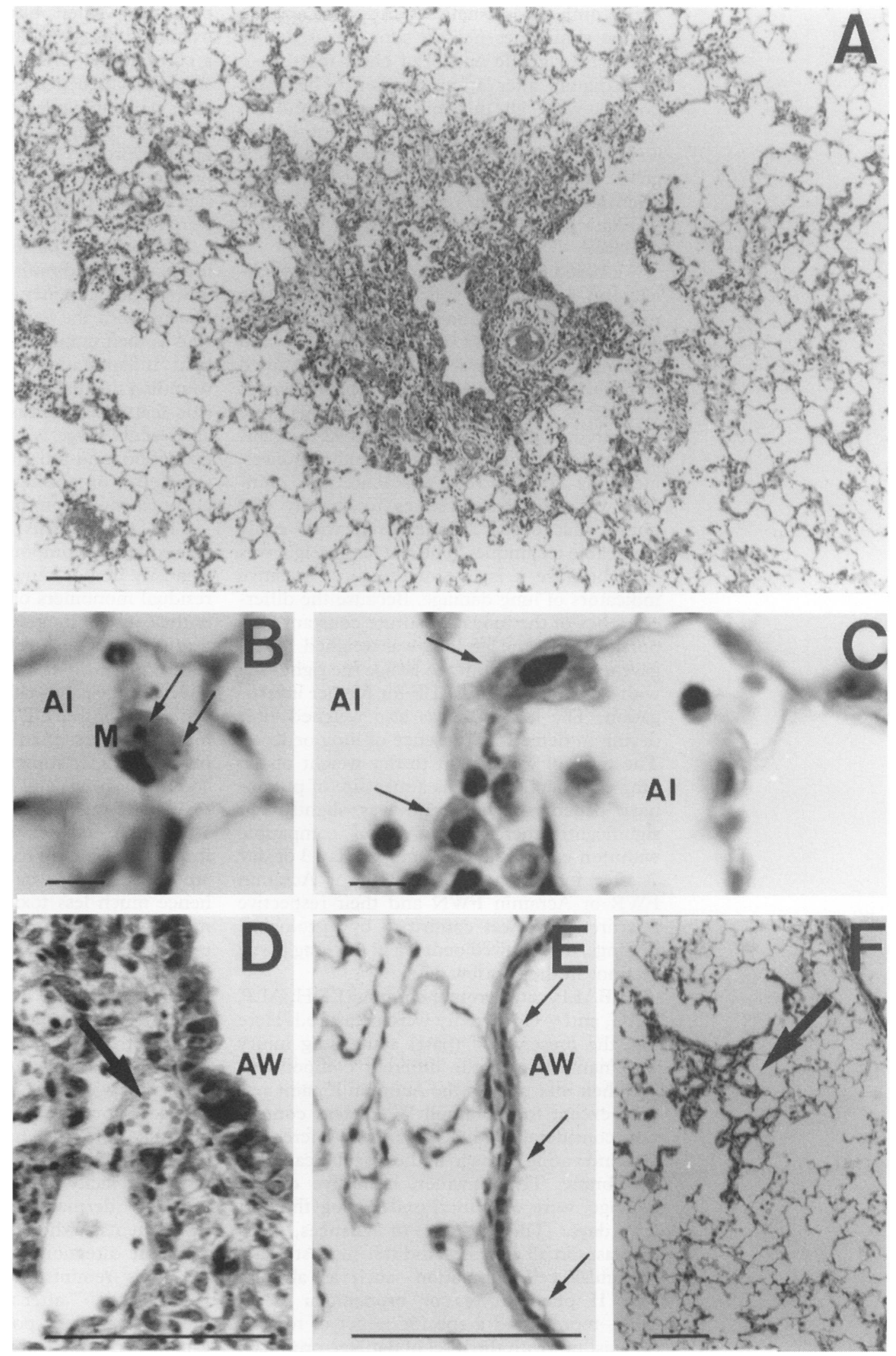

Figure 4 (A) Section on day 3 after a single intratracheal instillation of $16.5 \mathrm{mg} / \mathrm{kg}$ Acramin $F W N$, showing inflammation confined to the centrilobular areas. The same type of pathology was also found after instillation of Acramin FWR, Acrafix FHN, or mixtures 1, 2, or 3. (B) Detail of a section through lung tissue on day 3 after instillation of mixture 2, showing inclusions in macrophages (M) in the alveoli (arrows). These granules were also present in the cytoplasm of macrophages in lung tissues after instillation of all the other compounds tested, including Acramoll W. $(C)$ cytoplasm of macrophages in lung tissues after instillation of all the other compounds tested, including Acramoll W. (C)
Detail on day 3 after instillation of mixture 3, showing hyperactive and hyperplastic alveolar type II cells (arrows); Al=alveolus. (D) Detailed section of lung tissue on day 3 after instillation of $2.0 \mathrm{mg} / \mathrm{kg}$ Acramin $F W R$ showing a stressed epithelial lining of the airways ( $A W$ ). Clara cells are lacking. The presence of red blood cells (arrow) is notable in the alveoli. (E) Detailed section of lung tissue on day 3 after instillation of PBS, showing no alveolar damage, and a normal epithelial lining of the airways (AW). Clara cells (arrows) are present. (F) Section through lung tissue on day 92 after instillation of mixture 3, showing sequelae of inflammation (arrow). Thickened alveolar septa represent collagen deposition. $B a r=100 \mu m(A, D, E, F)$, bar $=10 \mu m(B, C)$. 
these compounds usually led to apnoea and the animal sometimes needed some resuscitation - that is, a gentle and brief chest massageimmediately after administration. The compounds were all miscible in water and no deaths from mechanical obstruction of the airways were found. On the contrary, there was good evidence, both macroscopically and microscopically, that a good dispersion of the instillate into the lung parenchyma had been achieved.

We based our assessment of pulmonary toxicity on a standard approach ${ }^{14}$ combining $^{15}$ measurements of wet and dry lung weights, and several relevant end points in BALF and histology, with all these indices being obtained from the same animal, to keep the numbers of animals as low as possible. End points were measured on days $3,7,14,28$, and 92 to evaluate both acute and possible delayed responses, including fibrosis. To assess acute lung damage, we restricted ourselves to toxicity end points that could be measured with easily applicable techniques. The wet lung weight was used because it is one of the most sensitive indicators of lung damage. Because the different lobes of the lungs constitute constant proportions, only the left lung was weighed. ${ }^{15}$ This gave us the opportunity to lavage the right lung with saline to obtain BALF for further investigation. The left lung was also weighed after drying to detect the presence of lung oedema. The ratio of wet weight to dry weight of the lung can then be used as a measure of pulmonary oedema. ${ }^{16}$ This ratio was slightly but significantly increased, to values compatible with non-cardiogenic oedema, on day 3 or day 7 after intratracheal instillation of Acramin FWR or Acramin FWN and their respective mixtures. This was confirmed by histological findings, that showed oedema in the lung tissue sections in the first few days.

In BALF, total protein content, $\mathrm{LDH}, \mathrm{ALP}$, NAG, and $\gamma$-GT activity were measured. Here too, the presence of (past) acute lung injury was manifest with the different components, and their mixtures, of the Acramin F paint system, except for Acramoll W. Protein content was considerably and persistently increased, thus indicating damage to the alveolar capillary membrane. The enzymes, indicative of cell damage, were only increased during the first few days. The pattern of changes, with increases in all enzymes, did not suggest that a particular cell population-such as alveolar type II pneumocytes or bronchiolar Clara cells-represented a specific target of toxicity (at least not with the level of damage produced here). This was confirmed by histology which also showed a diffuse pattern of toxicity with involvement of the centrilobular alveolar and bronchiolar epithelium.

Changes in the cellular composition in BALF involved increments in total cell numbers and shifts in the proportions of the different cell types. The changes consisted mainly of an increase in total cell number which was mainly due to an increase in polymorphonuclear neutrophils thus indicating pulmonary acute inflammation. These findings were also confirmed when lung tissue sections were examined histologically. Due to the housing in a conventional animal house, control animals showed a high percentage of polymorphonuclear neutrophils from day 14, but there were no other signs of injury in these animals. Hydroxyproline was consistently increased beyond the acute phase. Histologically, no signs of (cryptogenic) organising pneumonia were found.

Summarising our results, it is concluded that intratracheal administration of the different individual components of the Acramin F paint system, with the exception of Acramoll W, as well as their combinations, resulted in a fulminant inflammation of the parenchyma surrounding the distal bronchioles with characteristic features of diffuse alveolar damage. The early acute stage is characterised by oedema, exudation, and inflammation, and in a second stage, the organising stage, scarring fibrosis becomes more dominant. ${ }^{17}$

The mechanisms for the lung damage caused by the compounds studied here are not clear. We do not know whether the presence of residual monomers or oligomers played a part in the cause of lung injury, but we do not think that this was so. A role for diethylenetriamine (DETA, see fig 1) in the toxicity of Acramin FWN can be safely ruled out, because the concentration of free DETA in Acramin FWN was found to be less than $1 \%$ by gas chromatography - mass spectrometry (W Pauwels, personal communication) and because the intratracheal toxicity of pure DETA (intratracheal $\mathrm{LD}_{50}=$ $141 \mathrm{mg} / \mathrm{kg}$, data not shown) could not account for that of Acramin FWN. In general, polymers are considered to be much less reactive and hence much less toxic than, for example, the monomers which they are made of. The low reactivity and toxicity of most polymers is manifested in their generally low oral toxicity and low degree of dermal or ocular irritancy and this inert behaviour is widely accepted to indicate that polymers possess a low degree of toxicity to the respiratory tract. However, it is likely that we should revise this simplistic view. Indeed, Klonne et $a l^{1819}$ have shown that some polymers of ethylene oxide and propylene oxide may exhibit a much higher degree of pulmonary toxicity than is suggested by their lack of oral, dermal, or ocular toxicity. Our experiments, although limited, may point in the same direction, as the lung toxicity found by us is reminiscent of that described by Klonne et $a l^{18}{ }^{19}$ after the inhalation of some of these polyalkylene polymers. It remains to be established which physicochemical properties (chain length, shape and structure, detergent effects, electrical charges, reactive groups) of polymers are critical for causing lung damage, because not all copolymers based on ethylene oxide or propylene oxide show toxicity. ${ }^{20}$ In this respect it is obvious from our results that not every intratracheally instilled polymer is capable, regardless of its nature, of causing lung damage, because Acramoll W proved to be very well tolerated. In other words, the increases of the variables measured on day 3 after intratracheal instillation are not just caused by the 
instillation of a chemical, but they are caused by the toxic action of the chemical instilled. It is important to elucidate the mechanisms for this surprising degree of pulmonary damage caused by some polymers, because it might help us to devise tests to predict a discrepancy between mucocutaneous irritant potential and the ability to cause serious lung injury. The signs of damage in the late phase seemed to result more from the healing of past injury, rather than from a continuing inflammatory process with organising pneumonia and active fibrosis. In this respect, our experimental model does not seem to be valid for the study of the human Ardystil syndrome, which is characterised by organising pneumonia, but this was not the purpose of this study, which sought to determine the acute pulmonary toxicity of the suspected causal agent.

Taking all results together and notwithstanding the few animals used, the main conclusion of our exploratory study is that there is no significant difference, in hamsters, between the acute pulmonary (intratracheal) toxicity of Acramin FWR and that of Acramin FWN. Paint mixtures containing Acramin FWN (mixture 2 and mixture 3 ) seem to be significantly more toxic than mixture 1 (containing Acramin FWR) for some variables (wet lung weight, $\mathrm{LDH}$ and ALP activity in BALF) but the differences are not considerable. The addition of white spirit and acetic acid to mixture 2 did not result in increased toxicity. Differences between the tested compounds occur only in the acute response phase (days 3 and 7 ), but not in the late response phase. Although we found no support for the epidemiological hypothesis that Acramin FWN is more toxic than Acramin FWR, we were surprised by the relatively high toxicity of both these nonirritant agents in the lungs. The Ardystil disaster and our results should serve as a strong warning that conventional toxicity testing of chemicals does not necessarily protect workers against respiratory toxicity.

We must conclude from our study that we cannot offer a simple toxicological support, let alone explanation, for the epidemiological hypothesis that the Ardystil syndrome was caused by the replacement of Acramin FWR by Acramin FWN. One possibility is that the disease was not caused by the newly introduced agent. Maybe the formulation change was coincidental and the disaster would have occurred anyway because of the high air concentrations of aerosolised paint or the use of solvents. Alternatively, the disease may have been caused by another substance-for example, a cross linking agent-as has been speculated on circumstantial grounds. ${ }^{21}$ Another possibility is that the introduction of Acramin FWN did cause the outbreak but that our experimental model was not valid to show this. Several reasons may be envisaged in this case: the animal species chosen was not appropriate, the effect of a single intratracheal administration does not reflect the toxicity of repeated exposures by inhalation, the aerosol characteristics were changed by the introduction of Acramin FWN, the disease was not caused by simple toxicity but by an immunological mechanism. Some of these options are testable experimentally and, as indicated before, we think that the unusual severity of the disease warrants serious efforts to solve this important toxicological puzzle. A new study, comparing the effects of Acramin FWR and Acramin FWN after a two week inhalation period is now in progress. In vitro toxicity tests have also been initiated.

We thank Mrs Katrien Konings, Mrs Josianne Brebels, Mr Hadewijch Van Hooren, and Ms Cindy Mandervelt for their technical support. No specific financial support was received for this study. BN is holder of the Dr P Tuytens chair in toxicology. FC was supported by a grant from the Nationaal Fonds voor Wetenschappeliik On a grant frolgium (Actie Levenslijn-1994). Wetenschappeli)k Onderzoek, Belgium (Actie Levenslijn-1994). Preliminary form, at the British Association for Lung Research (Edinburgh, September 1995), the European Respiratory Society (Barcelona,
September 1995), and the American Thoracic Society (New September 1995), and
Orleans, May 1996).

1 Moya C, Antó JM, Newman Taylor AJ, the collaborative group for the study of toxicity in textile aerographic factories. Outbreak of organising pneum

2 Ould Kadi F, Mohammed-Brahim B, Fyad A, Lellou S, Nemery B. Outbreak of pulmonary disease in textile dye sprayers in Algeria. Lancet 1994;344:962-3.

3 Riveira Rico V, Sanz Gallen P, Pou Serra R. Hipótesis sobre los agentes causales del brote epidémico en aerografia textil. Resumen de hechos relevantes y avance de hipótesis sobre el agente causal de la afectación de los trabajadores de la actividad de aerografia textil en la comunidad Valenciana. Barcelona: 1993. (Report T-1355/93 R-9/3.)

4 Clottens FL, Oehrens AM, Verbeken EK, Hoet PHM, Clottens FL, Oehrens AM, Verbeken EK, Hoet PHM,
Demedts $M$, Nemery B. Comparison of the acute Demedts $M$, Nemery $B$. Comparison of the acute
pulmonary toxicity of textile paint components linked to pulmonary toxicity of textile paint components linked to Med 1996;153:A474.

5 Weil CS. Tables for convenient calculation of medianeffective dose $\left(\mathrm{LD}_{50}\right.$ or $\left.\mathrm{ED}_{50}\right)$ and instructions in their use. Biometrics 1952;8:249-63.

6 Bradford MM. A rapid and sensitive method for the quantitation of microgram quantities of protein utilizing the principle of protein-dye binding. Anal Biochem 1976;72:24854.

7 Vassault A. Lactate dehydrogenase. UV-method with pyruvate and NADH. In: Bergmeyer HU, ed. Methods of pyruvate and NADH. In: Bergmeyer HU, ed. Methods of enzymatic analysis, 3th ed. Vol III: enzymes I:

8 Horak E, Hopfer SM, Sunderman Jr, FW. Spectrophotometric assay for urinary N-acetyl- $\beta$-D-glucosaminidase. Clin Chem 1981;27:1180-5.

9 Woessner Jr, JF. The determination of hydroxyproline in tissue and protein samples containing small proportions of this imino acid. Arch Biochem Biophys 1961;93:440-7.

10 Dorries AM, Valberg PA. Heterogeneity of phagocytosis for inhaled versus instilled material. Am Rev Respir Dis 1992;146:831-7.

11 Driscoll KE, Maurer JK, Lindenschmidt RC, Romberger D, Rennard SI, Crosby L. Respiratory tract responses to dust: relationships between dust burden, lung injury, alveolar macrophage fibronectin release, and the development of pulmonary fibrosis. Toxicol Appl Pharmacol 1990;106:88pulm.

12 Beck BD, Brain JD, Bohannon DE. An in vivo hamster bioassay to assess the toxicity of particulates for the lungs. Toxicol Appl Pharmacol 1982;66:9-29.

13 Cantor JO. Bleomycin-induced pulmonary fibrosis. In: Candor JO, ed. Handbook of animal models of pulmonary disease. Vol I. Boca Raton: CRC Press, 1989.

14 Henderson RF. Use of bronchoalveolar lavage to detect lung damage. Environ Health Perspect 1984;56:115-29.

15 Nemery B, Dinsdale D, Verschoyle RD. Detecting and evaluating chemical-induced lung damage in experimental evaluating chemical-induced lung damage in experim
animals. Bull Eur Physiopathol Respir 1987;23:501-28.

16 Cross CE, Parsons GH, Gorin AB, Last JA. Pulmonary edema: emphasis on physiologic and toxicological considerations. In: Witschi HP, Nettesheim P, eds. Mechanisms in respiratory toxicology. Vol 1. Boca Raton: CRC Press, 1982.

17 Katzenstein ALA, Askin FB. Surgical pathology of non neoplastic lung disease. Philadelphia: WB Saunders, 1982.

18 Klonne DR, Nachreiner DJ, Dodd DE, Losco PE, Tyler TR. Acute and 2-week inhalation toxicity studies on aerosols of selected ethylene oxide/propylene oxide polymers in rats. Fundam Appl Toxicol 1987;9:773-84.

19 Klonne DR, Dodd DE, Losco PE, Troup CM, Tyler TR. Pulmonary fibrosis produced in F-344 rats by subchronic inhalation of aerosols of a 4000 molecular weight ethylene oxide/propylene oxide polymer. Fundam Appl Toxicol 1988; 10:682-90.

20 Ulrich CE, Geil RG, Tyler TR, Kennedy Jr GL, Birnbaum HA. Two-week aerosol inhalation study in rats of ethylene oxide/propylene oxide copolymers. Drug Chem Toxicol oxide/propylene

21 Sanz P, Prat A. Toxicity in textile air-brushing in Spain. Lancet 1993;342:240. 
Appendix 1: Left lung weight and ratios and hydroxyproline content of hamsters after intratracheal instillation with different Acramin compounds

\begin{tabular}{|c|c|c|c|c|c|}
\hline \multirow[b]{2}{*}{ Exposure condition } & \multicolumn{2}{|l|}{ Body weight } & \multicolumn{2}{|l|}{ Left lung } & \multirow[b]{2}{*}{$\begin{array}{l}\text { Hydroxyproline } \\
\text { ( } \mu \mathrm{g} / \text { dried left lung) }\end{array}$} \\
\hline & Final weight $(g)$ & $\begin{array}{l}\text { Percentage of initial } \\
\text { weight }(\%)\end{array}$ & $\begin{array}{l}\text { Weight }(\mathrm{mg} / 100 \mathrm{~g} \\
\text { body weight) }\end{array}$ & $\begin{array}{l}\text { Ratio (wet weight/dry } \\
\text { weight) }\end{array}$ & \\
\hline & Day 3 & & & & \\
\hline PBS-Control & $119(6)$ & $100.7(1.2)$ & 167.0 & $4.75(0.12)$ & $435(42)$ \\
\hline Acramoll W & $118(16)$ & $100.8(1.2)$ & $180.2(6.4)$ & $4.71(0.13)$ & $411(46)$ \\
\hline Acrafix FHN & $104(7)$ & $95.1(0.7)^{\star}$ & $264.4(17.6)^{\star}$ & $4.85(0.08)$ & $489(47)$ \\
\hline Acramin FWR & $90(9)$ & $92.0(1.2)^{\star}$ & $393.6(24.6)^{\star}$ & $4.77(0.71)$ & $529(105)$ \\
\hline Mixture 1 & $96(13)$ & $91.9(1.9)^{\star}$ & $441.3(26.3)^{\star}$ & $5.06(0.12)^{\star}$ & $545(75)^{\star}$ \\
\hline Acramin FWN & $97(8)$ & $93.5(1.2)^{\star}$ & $349.0(64.5)^{\star}$ & $5.20(0.15)^{\star}$ & $525(58)$ \\
\hline Mixture 2 & $97(15)$ & $90.0(1.5)^{\star}$ & $520.9(63.0)^{\star}$ & $5.11(0.24)^{\star}$ & $589(84)^{\star}$ \\
\hline Mixture 3 & $\begin{array}{l}101(11) \\
\text { Day } 7\end{array}$ & $88.6(0.5)^{\star}$ & $533.0(44.1)^{\star}$ & $5.21(0.14)^{\star}$ & $641(40)^{\star}$ \\
\hline PBS-Control & $109(11)$ & $109.2(3.4)$ & $167.8(9.6)$ & $4.82(0.11)$ & $467(46)$ \\
\hline Acramoll W & $115(9)$ & $111.2(2.4)$ & $159.8(13.6)$ & $4.74(0.22)$ & $438(37)$ \\
\hline Acrafix FHN & $121(8)$ & $105.7(2.2)$ & $198.6(15.0)$ & $4.93(0.13)$ & $540(66)$ \\
\hline Acramin FWR & $96(4)$ & $102.4(2.8)^{\star}$ & $304.6(22.1)^{\star}$ & $5.14(0.11)^{\star}$ & $628(31)^{\star}$ \\
\hline Mixture 1 & $108(6)$ & $101.8(4.0)^{\star}$ & $268.8(29.0)^{\star}$ & $5.01(0.17)$ & $653(47)^{\star}$ \\
\hline Acramin FWN & $95(3)$ & $103.1(3.4)^{\star}$ & $260.2(19.8)^{\star}$ & $5.01(0.16)$ & $587(68)^{\star}$ \\
\hline Mixture $2(n=4)$ & $97(19)$ & $94.3(8.5)^{\star}$ & $387.4(134.2)^{\star}$ & $5.15(0.11)^{\star}$ & $780(34)^{\star}$ \\
\hline Mixture $3(n=4)$ & $\begin{array}{l}98(8) \\
\text { Day } 14\end{array}$ & $98.5(1.7)^{\star}$ & $370.7(65.8)^{\star}$ & $5.23(0.20)^{\star}$ & $835(71)^{\star}$ \\
\hline PBS-Control & $85(5)$ & $113.9(1.8)$ & $187.7(17.5)$ & $4.82(0.27)$ & $345(29)$ \\
\hline Acramoll W & $91(6)$ & $115.7(6.8)$ & $182.5(7.7)$ & $4.78(0.05)$ & $363(27)$ \\
\hline Acrafix FHN & $95(16)$ & $112.4(6.9)$ & $178.7(3.6)$ & $4.71(0.08)$ & $443(98)^{\star}$ \\
\hline Acramin FWR & $95(18)$ & $104.9(5.9)^{\star}$ & $295.6(82.4)^{\star}$ & $5.09(0.25)$ & $662(101)^{\star}$ \\
\hline Mixture 1 & $86(7)$ & $108.7(2.1)$ & $271.1(61.2)^{\star}$ & $5.06(0.19)$ & $555(39)^{\star}$ \\
\hline Acramin FWN & $104(12)$ & $100.9(4.9)^{\star}$ & $252.2(18.8)^{\star}$ & $5.05(0.10)$ & $653(100)^{\star}$ \\
\hline Mixture 2 & $102(8)$ & $105.1(4.1)^{\star}$ & $275.1(66.4)^{\star}$ & $4.96(0.19)$ & $751(146)^{\star}$ \\
\hline Mixture 3 & $\begin{array}{l}93(11) \\
\text { Day } 28\end{array}$ & $109.7(3.2)$ & $266.0(59.2)^{\star}$ & $5.00(0.07)$ & $719(76)^{\star}$ \\
\hline PBS-Control & $102(6)$ & $103.6(2.9)$ & $177.4(13.8)$ & $4.69(0.04)$ & $410(27)$ \\
\hline Acramoll W & $96(10)$ & $104.9(2.2)$ & $199.5(21.6)$ & $4.72(0.16)$ & $446(13)$ \\
\hline Acrafix FHN $(n=4)$ & $89(10)$ & $112.3(3.0)^{\star}$ & $192.4(22.1)$ & $4.72(0.05)$ & $381(47)$ \\
\hline Acramin FWR & $89(8)$ & $112.3(7.1)$ & $233.8(30.7)^{\star}$ & $4.74(0.07)$ & $580(86)^{\star}$ \\
\hline Mixture 1 & $93(7)$ & $106.3(2.7)$ & $236.5(32.7)^{\star}$ & $4.85(0.08)^{\star}$ & $634(99)^{\star}$ \\
\hline Acramin FWN & $91(11)$ & $120.9(12.3)^{\star}$ & $192.5(20.4)$ & $4.72(0.07)$ & $461(50)$ \\
\hline Mixture 2 & $108(9)$ & $109.8(7.0)$ & $208.6(21.9)$ & $4.64(0.14)$ & $718(86)^{\star}$ \\
\hline Mixture $3(n=3)$ & $\begin{array}{l}108(11) \\
\text { Day } 92\end{array}$ & $122.2(15.0)^{\star}$ & $202.5(19.7)$ & $4.68(0.28)$ & $617(96)^{\star}$ \\
\hline PBS-Control & $111(12)$ & $155.2(16.5)$ & $195.3(15.2)$ & $4.67(0.16)$ & $404(42)$ \\
\hline Acramoll W & $114(21)$ & $140.7(7.3)$ & $199.3(4.7)$ & $4.64(0.17)$ & $412(55)$ \\
\hline Acrafix FHN & $109(18)$ & $141.7(8.5)$ & $215.6(17.9)$ & $4.64(0.13)$ & $429(53)$ \\
\hline Acramin FWR & $123(22)$ & $145.9(16.2)$ & $216.8(13.6)$ & $4.70(0.14)$ & $568(64)^{\star}$ \\
\hline Mixture 1 & $114(17)$ & $143.9(13.4)$ & $244.8(33.6)^{\star}$ & $4.72(0.05)$ & $618(109)^{\star}$ \\
\hline Acramin FWN (n=4) & $127(16)$ & $144.7(12.3)$ & $200.1(25.2)$ & $4.72(0.13)$ & $556(59)^{\star}$ \\
\hline Mixture $2(n=4)$ & $113(4)$ & $144.8(3.4)$ & $246.6(69.6)$ & $4.68(0.15)$ & $610(141)^{\star}$ \\
\hline Mixture 3 & $109(13)$ & $142.2(18.1)$ & $249.6(60.1)$ & $4.66(0.07)$ & $592(114)^{\star}$ \\
\hline
\end{tabular}

$\star \mathrm{P}<0.05$; One way ANOVA applied to ranks (Kruskal-Wallis) followed by Dunnett's multiple comparisons test (treated $v$ control). No statistics were applied on final body weights, because initial body weights were not homogenously spread over all the groups. Unless otherwise stated $(n=5)$. Values are mean $(S D)$.

Appendix 2: Cell counts in BALF from hamsters after intratracheal instillation with different Acramin compounds

\begin{tabular}{|c|c|c|c|c|c|c|}
\hline \multirow[b]{3}{*}{ Exposure condition } & \multirow[b]{3}{*}{$\begin{array}{l}\text { Lavage recovered } \\
\text { (ml)t }\end{array}$} & \multirow[b]{3}{*}{$\begin{array}{l}\text { Total cell number/ } 4 \\
m l\left(x 10^{3}\right)\end{array}$} & \multicolumn{4}{|l|}{ Cells } \\
\hline & & & \multicolumn{2}{|l|}{ Macrophages } & \multicolumn{2}{|c|}{ Polymorphonuclear neutrophils } \\
\hline & & & $(\%)$ & $\begin{array}{l}\text { Absolute number } \\
\left(\times 10^{3}\right)\end{array}$ & $(\%)$ & $\begin{array}{l}\text { Absolute } \\
\text { number }\left(x 10^{3}\right)\end{array}$ \\
\hline & Day 3 & & & & & \\
\hline PBS-Control & $3.7(0.2)$ & $470(134)$ & $91.6(2.3)$ & $431(124)$ & $7.6(2.3)$ & $36(15)$ \\
\hline Acramoll W & $3.5(0.3)$ & $820(233)$ & $71.9(10.0)$ & $580(133)$ & $26.1(10.6)$ & $223(128)$ \\
\hline Acrafix FHN & $3.6(0.1)$ & $1824(521)^{\star}$ & $35.0(3.3)^{\star}$ & $638(187)$ & $63.3(4.1)^{\star}$ & $1157(351)^{\star}$ \\
\hline Acramin FWR & $3.6(0.2)$ & $2010(500)^{\star}$ & $35.6(6.5)^{\star}$ & $693(84)$ & $63.4(7.0)^{\star}$ & $1299(437)^{\star}$ \\
\hline Mixture 1 & $3.7(0.1)$ & $1471(627)^{\star}$ & $38.7(3.5)^{\star}$ & $555(206)$ & $60.3(4.4)^{\star}$ & $905(431)^{\star}$ \\
\hline Acramin FWN & $3.8(0.1)$ & $2357(768)^{\star}$ & $25.1(6.1)^{\star}$ & $559(111)$ & $73.7(6.0)^{\star}$ & $1769(692)^{\star}$ \\
\hline Mixture 2 & $3.7(0.1)$ & $2221(697)^{\star}$ & $33.3(4.7)^{\star}$ & $729(201)$ & $66.0(4.3)^{\star}$ & $1471(513)^{\star}$ \\
\hline Mixture 3 & $\begin{array}{l}3.7(0.2) \\
\text { Day } 7\end{array}$ & $2320(808)^{\star}$ & $35.5(5.1)^{\star}$ & $810(244)^{\star}$ & $63.8(5.4)^{\star}$ & $1497(604)^{\star}$ \\
\hline PBS-Control & $3.6(0.2)$ & $468(90)$ & $95.2(1.2)$ & $446(84)$ & $4.3(1.4)$ & $20(9)$ \\
\hline Acramoll W & $3.7(0.2)$ & $638(172)$ & $92.7(3.2)$ & $591(160)$ & $6.9(3.1)$ & $44(25)^{\star}$ \\
\hline Acrafix FHN & $3.6(0.2)$ & $1054(133)^{\star}$ & $83.1(2.3)$ & $876(115)^{\star}$ & $16.6(2.4)$ & $175(31)^{\star}$ \\
\hline Acramin FWR & $3.5(0.2)$ & $924(189)^{\star}$ & $67.4(5.8)^{\star}$ & $626(149)$ & $32.2(5.6)^{\star}$ & $295(67)^{\star}$ \\
\hline Mixture 1 & $3.5(0.2)$ & $771(104)^{\star}$ & $58.0(9.4)^{\star}$ & $446(91)$ & $41.9(9.5)^{\star}$ & $323(79)^{\star}$ \\
\hline Acramin FWN & $3.6(0.1)$ & $942(282)^{\star}$ & $65.8(7.8)^{\star}$ & $603(87)$ & $33.6(8.0)^{\star}$ & $334(197)^{\star}$ \\
\hline Mixture $2(n=4)$ & $3.4(0.3)$ & $963(419)^{\star}$ & $64.8(16.5)^{\star}$ & $582(133)$ & $35.0(16.5)^{\star}$ & $380(357)^{\star}$ \\
\hline Mixture $3(n=4)$ & $\begin{array}{l}3.6(0.2) \\
\text { Day } 14\end{array}$ & $1263(271)^{\star}$ & $73.0(9.1)^{\star}$ & $918(193)^{\star}$ & $26.8(9.1)^{\star}$ & $343(144)^{\star}$ \\
\hline PBS-Control & $3.6(0.3)$ & $830(310)$ & $79.3(12.4)$ & $630(138)$ & $20.2(11.9)$ & $195(175)$ \\
\hline Acramoll W & $3.6(0.3)$ & $811(327)$ & $86.5(11.0)$ & $680(188)$ & $13.3(10.8)$ & $129(167)$ \\
\hline Acrafix FHN & $3.7(0.1)$ & $842(116)$ & $89.9(7.2)$ & $751(53)$ & $10.0(7.3)$ & $90(82)$ \\
\hline Acramin FWR & $3.6(0.2)$ & $1358(526)$ & $59.9(15.7)^{\star}$ & $795(298)$ & $40.1(15.7)^{\star}$ & $563(340)$ \\
\hline Mixture 1 & $3.5(0.1)$ & $1316(473)$ & $46.9(14.7)^{\star}$ & $566(73)$ & $52.6(14.4)^{\star}$ & $742(456)^{\star}$ \\
\hline
\end{tabular}




\begin{tabular}{|c|c|c|c|c|c|c|}
\hline \multirow[b]{3}{*}{ Exposure condition } & \multirow[b]{3}{*}{$\begin{array}{l}\text { Lavage recovered } \\
(m l) t\end{array}$} & \multirow[b]{3}{*}{$\begin{array}{l}\text { Total cell number/ } 4 \\
m l\left(x 10^{3}\right)\end{array}$} & \multicolumn{4}{|l|}{ Cells } \\
\hline & & & \multicolumn{2}{|l|}{ Macrophages } & \multicolumn{2}{|c|}{ Polymorphonuclear neutrophils } \\
\hline & & & (\%) & $\begin{array}{l}\text { Absolute number } \\
\left(\times 10^{3}\right)\end{array}$ & $(\%)$ & $\begin{array}{l}\text { Absolute } \\
\text { number }\left(x 10^{3}\right)\end{array}$ \\
\hline Acramin FWN & $3.6(0.2)$ & $996(375)$ & $59.9(15.3)$ & $475(187)$ & $39.8(15.1)$ & $418(245)$ \\
\hline Mixture 2 & $3.6(0.1)$ & $1073(374)$ & $81.1(5.2)$ & $858(252)$ & $18.8(5.2)$ & $213(127)$ \\
\hline Mixture 3 & $\begin{array}{l}3.5(0.1) \\
\text { Day } 28\end{array}$ & $1085(138)$ & $81.2(4.9)$ & $879(99)$ & $18.4(5.2)$ & $203(72)$ \\
\hline PBS-Control & $3.8(0.1)$ & 590 (139) & $90.3(18.4)$ & $526(148)$ & $9.7(18.4)$ & $65(126)$ \\
\hline Acramoll W & $3.6(0.2)$ & $711(258)$ & $95.4(4.0)$ & $670(208)$ & $4.6(4.0)$ & $40(52)$ \\
\hline Acrafix FHN $(n=4)$ & $3.8(0.0)$ & $556(163)$ & $96.0(2.8)$ & $534(163)$ & $4.0(2.8)$ & $22(14)$ \\
\hline Acramin FWR & $3.6(0.1)$ & $794(202)$ & $87.2(3.4)$ & $693(188)$ & $12.8(3.4)$ & $101(34)^{\star}$ \\
\hline Mixture 1 & $3.5(0.2)^{\star}$ & $835(272)$ & $68.9(8.4)^{\star}$ & $558(104)$ & $31.1(8.3)^{\star}$ & $276(174)^{\star}$ \\
\hline Acramin FWN & $3.7(0.0)$ & $524(260)$ & $86.7(8.6)$ & $466(275)$ & $13.3(8.6)$ & $58(33)$ \\
\hline Mixture 2 & $3.7(0.5)$ & 729 (235) & $81.9(7.9)^{\star}$ & $588(148)$ & $17.7(7.9)^{\star}$ & $138(104)^{\star}$ \\
\hline Mixture $3(n=3)$ & $\begin{array}{l}3.5(0.2) \\
\text { Day } 92\end{array}$ & $510(92)$ & $93.3(1.2)$ & $476(91)$ & $6.7(1.2)$ & $33(4)$ \\
\hline PBS-Control & $3.8(0.1)$ & $942(608)$ & $68.9(28.3)$ & $517(101)$ & $30.8(28.2)$ & $422(532)$ \\
\hline Acramoll W & $3.6(0.2)$ & $1056(886)$ & $69.2(33.7)$ & $505(101)$ & $30.8(33.7)$ & $550(791)$ \\
\hline Acrafix FHN & $3.7(0.1)$ & $1240(684)$ & $56.7(31.7)$ & $540(91)$ & $43.1(31.8)$ & $698(621)$ \\
\hline Acramin FWR & $3.6(0.1)$ & $579(112)$ & $89.0(5.5)$ & $517(120)$ & $10.8(5.6)$ & $60(29)$ \\
\hline Mixture 1 & $3.3(0.3)^{\star}$ & $1390(1382)$ & $65.1(24.2)$ & $643(159)$ & $34.6(24.2)$ & 743 (1231) \\
\hline Acramin FWN $(n=4)$ & $3.7(0.1)$ & $1204(1042)$ & $72.8(31.0)$ & $636(150)$ & $27.1(31.1)$ & $568(967)$ \\
\hline Mixture $2(n=4)$ & $3.5(0.2)^{\star}$ & $1632(1477)$ & $54.0(33.3)$ & $564(102)$ & 45.9 (33.4) & $1068(1383)$ \\
\hline Mixture 3 & $3.5(0.4)$ & $1478(864)$ & 53.7 (31.5) & 578 (117) & $46.2(31.4)$ & $897(813)$ \\
\hline
\end{tabular}

$\star \mathrm{P}<0.05$; One way ANOVA applied to ranks (Kruskal-Wallis) followed by Dunnett's multiple comparisons test (treated $v$ control). † Pooled lavages (total volume instilled: $4 \times 1 \mathrm{ml}$ ).

Unless otherwise stated $(n=5)$. Values are mean (SD).

Appendix 3: Indices in bronchoalveolar lavage from hamsters after intratracheal instillation with different Acramin compounds

\begin{tabular}{|c|c|c|c|c|c|}
\hline Exposure condition & Protein $(\mu \mathrm{g} / \mathrm{ml})$ & $\begin{array}{l}\text { Lactate } \\
\text { dehydrogenase (U/l) }\end{array}$ & $\begin{array}{l}\text { Alkaline } \\
\text { phosphatase (U/l) }\end{array}$ & $\begin{array}{l}\beta \text {-N-acetyl } \\
\text { glucosaminidase (U/l) }\end{array}$ & $\begin{array}{l}\gamma \text {-glutamyl } \\
\text { transferase (U/l) }\end{array}$ \\
\hline & Day 3 & & & & \\
\hline PBS-Control & $119(11)$ & $27(10)$ & $1.9(2.0)$ & $1.8(0.4)$ & $2.2(0.9)$ \\
\hline Acramoll W & $144(9)$ & $34(3)$ & $1.3(0.6)$ & $2.0(0.5)$ & $2.0(0.8)$ \\
\hline Acrafix FHN & $826(154)^{\star}$ & $47(10)^{\star}$ & $2.4(0.7)$ & $3.2(0.6)$ & $1.7(0.7)$ \\
\hline Acramin FWR & $1288(281)^{\star}$ & $90(16)^{\star}$ & $4.9(2.0)^{\star}$ & $6.0(0.8)^{\star}$ & $4.4(0.5)^{\star}$ \\
\hline Mixture 1 & $1604(462)^{\star}$ & $88(25)^{\star}$ & $3.9(2.0)$ & $7.2(1.6)^{\star}$ & $4.9(2.5)^{\star}$ \\
\hline Acramin FWN & $1386(289)^{\star}$ & $170(26)^{\star}$ & $6.8(0.4)^{\star}$ & $11.2(5.1)^{\star}$ & $6.0(2.2)^{\star}$ \\
\hline Mixture 2 & $3080(1603)^{\star}$ & $218(117)^{\star}$ & $7.4(2.7)^{\star}$ & $15.3(7.4)^{\star}$ & $8.9(2.5)^{\star}$ \\
\hline Mixture 3 & $\begin{array}{l}1364(524)^{\star} \\
\text { Day } 7\end{array}$ & $221(62)^{\star}$ & $9.9(2.6)^{\star}$ & $7.7(2.0)^{\star}$ & $6.1(0.9)^{\star}$ \\
\hline PBS-Control & $108(11)$ & $39(11)$ & $2.1(0.7)$ & $1.9(0.4)$ & $4.5(1.9)$ \\
\hline Acramoll W & $114(11)$ & $34(21)$ & $2.5(1.2)$ & $2.2(0.3)$ & $3.5(0.9)$ \\
\hline Acrafix FHN & $288(7)^{\star}$ & $44(7)$ & $3.8(3.0)$ & $2.0(0.2)$ & $3.5(0.6)$ \\
\hline Acramin FWR & $134(8)^{\star}$ & 49 (14) & $2.2(0.3)$ & $1.9(0.6)$ & $6.0(1.2)$ \\
\hline Mixture 1 & $273(16)^{\star}$ & $48(12)$ & $2.7(0.4)$ & $1.6(0.3)$ & $6.0(1.8)$ \\
\hline Acramin FWN & $157(19)^{\star}$ & $40(7)$ & $3.0(0.4)$ & $1.7(0.4)$ & $4.2(0.8)$ \\
\hline Mixture $2(n=4)$ & $376(224)^{\star}$ & $89(72)$ & $3.3(1.3)$ & $1.8(0.6)$ & $8.5(1.5)^{\star}$ \\
\hline Mixture $3(n=4)$ & $\begin{array}{l}331(267)^{\star} \\
\text { Day } 14\end{array}$ & $54(15)$ & $3.5(0.7)$ & $1.3(0.2)$ & $4.5(0.8)$ \\
\hline PBS-Control & $92(13)$ & $30(7)$ & $0.9(0.3)$ & $2.0(0.4)$ & $3.8(0.6)$ \\
\hline Acramoll W & $76(13)$ & 31 (18) & $0.8(0.4)$ & $1.7(0.3)$ & $3.8(1.1)$ \\
\hline Acrafix FHN & $108(17)$ & $33(14)$ & $1.3(0.3)$ & $1.5(0.2)$ & $5.0(0.9)$ \\
\hline Acramin FWR & $138(15)^{\star}$ & 43 (11) & $1.2(0.5)$ & $2.3(0.9)$ & $4.591 .9)$ \\
\hline Mixture 1 & $121(17)$ & 39 (19) & $1.6(1.2)$ & $2.1(0.5)$ & $4.2(1.4)$ \\
\hline Acramin FWN & $136(23)^{\star}$ & $36(7)$ & $2.0(0.8)^{\star}$ & $2.1(0.9)$ & $3.5(1.1)$ \\
\hline Mixture 2 & $143(11)^{\star}$ & $36(16)$ & $3.0(1.3)^{\star}$ & $2.3(0.7)$ & $4.0(0.6)$ \\
\hline Mixture 3 & $\begin{array}{l}140(30)^{\star} \\
\text { Day } 28\end{array}$ & $24(6)$ & $3.1(1.3)^{\star}$ & $1.8(0.3)$ & $4.4(1.5)$ \\
\hline PBS-Control & $103(9)$ & $10(7)$ & $2.1(0.9)$ & $1.0(0.3)$ & $1.1(0.8)$ \\
\hline Acramoll $\mathrm{W}$ & $102(14)$ & $18(4)$ & $2.3(0.4)$ & $1.1(0.2)$ & $1.6(0.4)$ \\
\hline Acrafix FHN (n=4) & $101(8)$ & $10(6)$ & $2.9(0.3)$ & $1.1(0.3)$ & $1.2(0.8)$ \\
\hline Acramin FWR & $109(15)$ & $22(8)$ & $2.5(0.7)$ & $1.3(0.3)$ & $2.1(0 . .5)$ \\
\hline Mixture 1 & $128(21)$ & $21(10)$ & $1.9(0.2)$ & $1.9(0.7)^{\star}$ & $2.1(0.8)$ \\
\hline Acramin FWN & $102(17)$ & $19(9)$ & $3.1(1.3)$ & $1.2(0.1)$ & $1.2(1.0)$ \\
\hline Mixture 2 & $132(12)$ & $34(12)^{\star}$ & $3.2(0.9)$ & $1.9(0.3)^{\star}$ & $2.9(1.0)^{\star}$ \\
\hline Mixture $3(n=3)$ & $\begin{array}{l}129(26) \\
\text { Day } 92\end{array}$ & $29(11)^{\star}$ & $3.0(0.9)$ & $1.7(0.1)$ & $1.9(1.7)$ \\
\hline PBS-Control & $155(29)$ & $26(11)$ & $3.3(1.9)$ & $2.3(0.5)$ & $2.3(0.5)$ \\
\hline Acramoll W & $149(27)$ & $32(23)$ & $3.2(2.0)$ & $2.3(1.0)$ & $1.5(1.6)$ \\
\hline Acrafix FHN & $179(42)$ & $32(17)$ & $4.0(2.2)$ & $2.4(1.1)$ & $2.5(1.3)$ \\
\hline Acramin FWR & $168(25)$ & $20(6)$ & $2.2(1.0)$ & $2.0(0.5)$ & $2.1(1.3)$ \\
\hline Mixture 1 & $221(18)^{\star}$ & $41(14)$ & $5.0(1.8)$ & $3.4(1.4)$ & $3.2(1.3)$ \\
\hline Acramin FWN $(n=4)$ & $159(29)$ & $26(25)$ & $5.0(3.8)$ & $2.5(1.2)$ & $2.3(0.9)$ \\
\hline Mixture $2(n=4)$ & $220(31)^{\star}$ & $57(18)$ & $8.2(6.0)$ & $5.0(3.7)$ & $3.6(0.9)$ \\
\hline Mixture 3 & $182(36)$ & $29(20)$ & $6.4(2.6)$ & $3.0(1.1)$ & $2.7(1.5)$ \\
\hline
\end{tabular}

${ }^{\star} \mathrm{P}<0.05$; One way ANOVA applied to ranks (Kruskal-Wallis) followed by Dunnett's multiple comparisons test (treated $v$ control). All results are expressed per $\mathrm{ml}$ or 1 BALF recovered.

Unless otherwise stated $(n=5)$. Values are mean (SD). 